\title{
Preferencje studentów kierunku pielęgniarstwo w zakresie zachowań zdrowotnych
}

\author{
Preferences of the Nursing Faculty Students in terms of Health Related Behaviour
}

\section{Streszczenie}

Wstęp. Zachowania zdrowotne determinują styl życia człowieka i w znacznym stopniu wpływają na stan zdrowia.

Cel. Celem pracy było poznanie i ocena zachowań zdrowotnych studentów kierunku pielęgniarstwo $\mathrm{z}$ uwzględnieniem wybranych uwarunkowań socjodemograficznych.

Materiał i metody. Badania zostały przeprowadzone wśród studentów studiów pierwszego stopnia na kierunku pielęgniarstwo. Wykorzystano metodę sondażu diagnostycznego a narzędziem badawczym kwestionariusz Inwentarza Zachowań Zdrowotnych (IZZ).

Wyniki. Respondenci najczęściej deklarowali preferowanie takich zachowań zdrowotnych jak: posiadanie przyjaciół i uregulowanego życia rodzinnego, ograniczanie palenia tytoniu, notowanie telefonów służb pogotowia. Niepokojącą sytuacją jest przeznaczanie zbyt małej ilości czasu na wypoczynek i dążenia do unikania przepracowania przez studentów.

Wnioski. Studenci kierunku pielęgniarstwo prezentują dobre postawy i preferencje w zakresie zachowań zdrowotnych. Płeć różnicowała wybrane zachowania zdrowotne badanych.

\begin{abstract}
:
Introduction. Health related behaviour determines the style of human life and significantly affects health . Objective. The aim of the research was to investigate and evaluate health behavior patterns of students with consideration of selected socio-demographic preconditions.

Material and methods. The research was conducted among Bachelor degree nursing students. The diagnostic survey method was applied, while the Health Behavior Inventory served as a research tool.

Results. The respondents most often declared to give preference to such health behaviour as stable family life, social life, restrictions on smoking/the use of tobacco and writing down emergency services phone numbers. Still, the worrying situation is the fact of devoting too little time for resting, and the students' continuous efforts to avoid any overworking.
\end{abstract}

Conclusion. Nursing students have good attitudes and preferences in terms of health related behaviour. It was gender that differentiated respective health related behaviour patterns.

Słowa kluczowe: zachowania zdrowotne, studenci, pielęgniarstwo

Key words: health related behaviour, students, nursing 


\section{Wstęp}

Zdrowie według Światowej Organizacji Zdrowia to stan pełnego, dobrego samopoczucia fizycznego, psychicznego i społecznego, a nie tylko brak choroby [1]. Jako wartość odgrywa bardzo ważną rolę w życiu człowieka, wpływając na preferowany styl życia i zachowania zdrowotne.

Koncepcja obszarów zdrowia została przedstawiona przez Marca Lalonde’a, który wyróżnił 4 grupy czynników mających wpływ na stan zdrowia ludności: obszar biologii i genetyki, zachowań i stylu życia, środowiskowy (do którego zalicza się czynniki ekonomiczne, społeczne, kulturowe i fizyczne) oraz obszar organizacji systemu ochrony zdrowia. Wymienione obszary znane są pod nazwą pól zdrowotnych Lalonde'a. Koncepcja ta została potwierdzona w 1948 roku w czterdziestoletnim programie badań nad czynnikami ryzyka chorób układu sercowo-naczyniowego. Wyniki niniejszego badania pozwoliły również uszeregować pola zdrowotne Lalonde’a według wielkości ich wpływu na stan zdrowia [2].

Stylem życia nazywamy cechy charakterystyczne dla zachowania się jednostki lub zbiorowości (środowiska społecznego, kręgu towarzyskiego, grupy wiekowej, mieszkańców), ujawniający się zwłaszcza w życiu codziennym w postawach wobec pracy, sposobach spędzania wolnego czasu, konsumpcji, stroju, stosunkach międzyludzkich itp. [3]. Dotyczy on również kategorii sposobu życia ludzi. W odniesieniu do zdrowia publicznego styl życia oznacza te działania jednostek, które służą utrzymaniu i polepszaniu stanu swojego zdrowia i zapobiegania chorobom [4].

Standard kształcenia dla kierunku pielęgniarstwo (studia pierwszego stopnia) wskazuje, że w ramach efektów kształcenia absolwent jest przygotowany m. in. do charakteryzowania i różnicowania pojęć zdrowia i choroby, promocji zdrowia, profilaktyki, zachowań zdrowotnych, stylu życia. Potrafi także rozpoznawać uwarunkowania zachowań zdrowotnych jednostki i czynniki ryzyka chorób wynikających ze stylu życia oraz czynnie uczestniczyć w projektowaniu metod, form profilaktyki i prewencji chorób oraz kształtowaniu prawidłowych zachowań zdrowotnych wobec różnych grup społecznych. Nabywa także umiejętności przygotowania odbiorcy usług pielęgniarskich do samokontroli stanu zdrowia i motywowania do zachowań prozdrowotnych [5].

W dobie transkulturowości koniecznym jest monitorowanie nie tylko stylu życia, ale i uwarunkowań wyborów zachowań zdrowotnych. Zachowania zdrowotne skupiają się na sposobie odżywiania, aktywności fizycznej, sposobie spędzania wolnego czasu, długości i jakości snu, uleganiu nałogom, narażeniu na zanieczyszczenia środowiska oraz dotyczą zachowań seksualnych. Najlepszą strategią poprawy sytuacji zdrowotnej społeczeństwa jest zatem promowanie i upowszechnianie prozdrowotnych zachowań w każdej dziedzinie życia ludzkiego. Zasadniczą kwestią pozostaje jednak preferowanie przez przedstawicieli systemu ochrony zdrowia takich zachowań $\mathrm{w}$ zakresie zdrowia, do których przestrzegania stymuluje się odbiorców świadczeń zdrowotnych.

Celem badań prezentowanych w opracowaniu była analiza zachowań zdrowotnych prezentowanych przez studentów kierunku pielęgniarstwo.

\section{Materiał i metody}

Badania o charakterze pilotażowym przeprowadzono wśród 49 studentów Państwowej Wyższej Szkoły Zawodowej we Włocławku. Respondentami byli studenci pierwszego roku studiów na kierunku pielęgniarstwo (studia pierwszego stopnia). Metodami zastosowanymi w badaniu był sondaż diagnostyczny oraz metoda szacowania. Wykorzystano technikę ankietowania i skali szacunkowej. W badaniach posłużono się kwestionariuszem IZZ (Inwentarz Zachowań 
Zdrowotnych), zakupionym w Pracowni Testów Psychologicznych Polskiego Towarzystwa Psychologicznego i uzupełnionym o metryczkę z danymi socjodemograficznymi respondentów. Kwestionariusz obejmował zagadnienia związane $\mathrm{z}$ zachowaniami zdrowotnymi m.in. takimi jak: unikanie palenia tytoniu, przeziębień, jedzenie owoców i warzyw, spożywanie pełnoziarnistego pieczywa, preferowanie odpowiedniej ilości wypoczynku, snu, posiadanie przyjaciół, unikanie silnych emocji stresów [6].

Udział $\mathrm{w}$ badaniach był dobrowolny i anonimowy. Opracowanie wyników badań $\mathrm{z}$ wykorzystaniem arkusza kalkulacyjnego przebiegało $\mathrm{w}$ kliku etapach. W pierwszym nastąpiła weryfikacja zebranych ankiet pod kątem kompletności oraz właściwego wypełnienia kwestionariuszy. Następnie przeanalizowano grupę badanych osób na podstawie zmiennych socjodemograficznych. W kolejnym etapie w celu dokładniejszej analizy cech mających wpływ na zachowania prozdrowotne porównano informacje zabrane $\mathrm{o}$ respondentach $\mathrm{z}$ ich odpowiedziami udzielonymi $\mathrm{w}$ kwestionariuszu IZZ. Dane przedstawiono $\mathrm{w}$ postaci tabel i wykresów. Na tej podstawie dokonano analizy statystycznej z wykorzystaniem liczebności respondentów, udziału procentowego, sumarycznej liczby punktów i średniej liczby punktów udzielonych na dane pytanie $\mathrm{z}$ uwzględnieniem zmiennych socjodemograficznych. Ostatnim etapem była analiza merytoryczna i interpretacja uzyskanych wyników.

Spośród rozprowadzonych 48 ankiet wyczerpujący materiał otrzymano od 43 osób. $\mathrm{Z}$ tego powodu do dalszych obliczeń wzięto pod uwagę tylko 43 kwestionariusze z kompletnymi odpowiedziami. Wskaźnik efektywności uzyskania danych wyniósł 89,6\%.

W badaniach wzięło udział więcej kobiet (88,4\% - 38 osób) niż mężczyzn (11,6\% 5 osób). Rozkład próby ze względu na płeć przedstawiono na rycinie 1.

\section{Rycina 1. Charakterystyka badanych ze względu na płeć.}
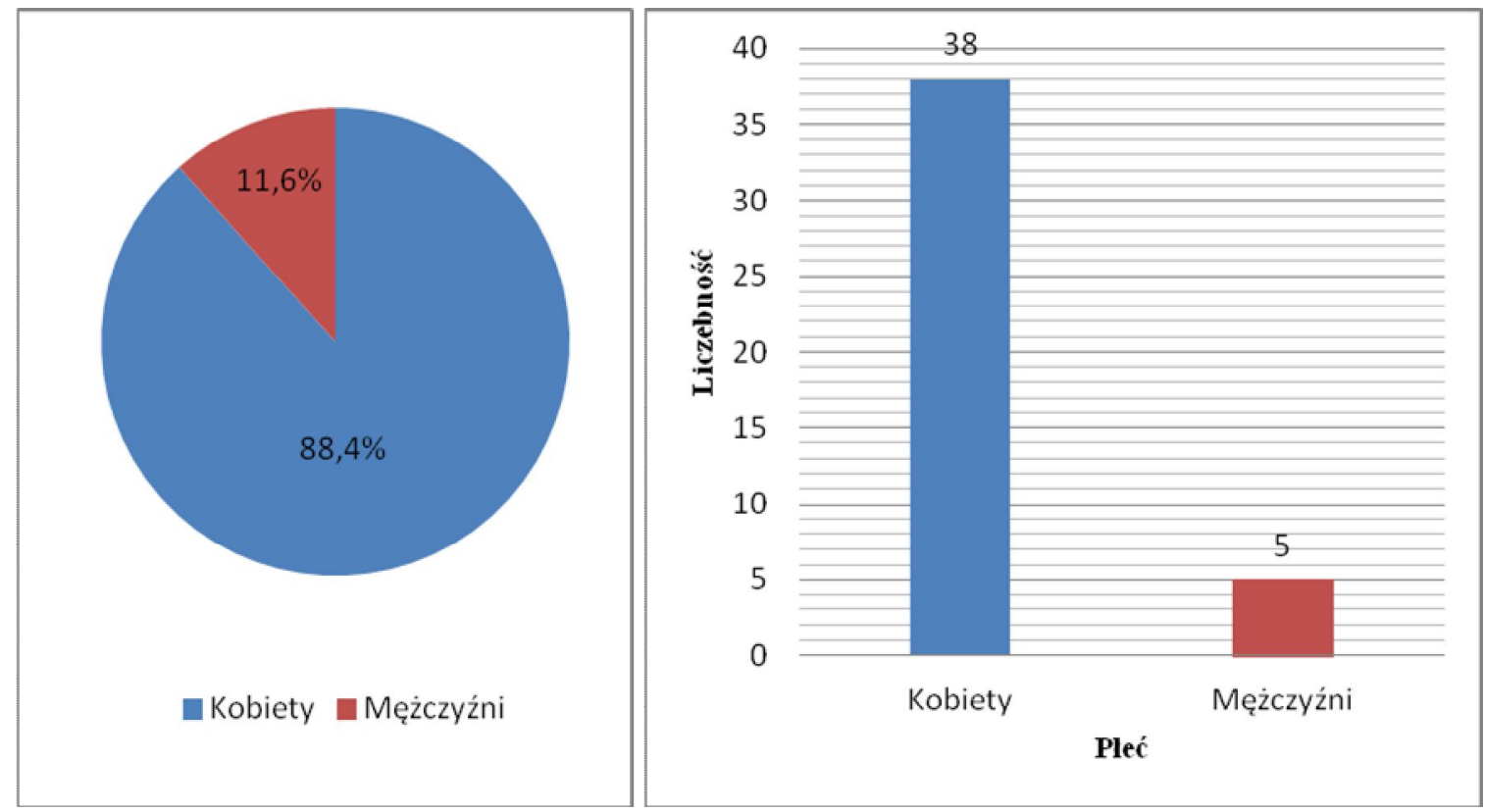

Źródło: opracowanie własne

Respondenci zostali podzieleni na pięć przedziałów wiekowych: 19-25, 26-30, 31-35, 3640, 41 i więcej. W grupie badanych zdecydowaną większość stanowili studenci w przedziale wiekowym 19-25 lat $(65,1 \%)$. Najmniejszą grupę tworzyli respondenci powyżej 41 roku życia $(2,3 \%)$. Szczegółową charakterystykę badanych ze względu na wiek przedstawiono na rycinie 2 . 


\section{Rycina 2. Charakterystyka badanych ze względu na wiek.}

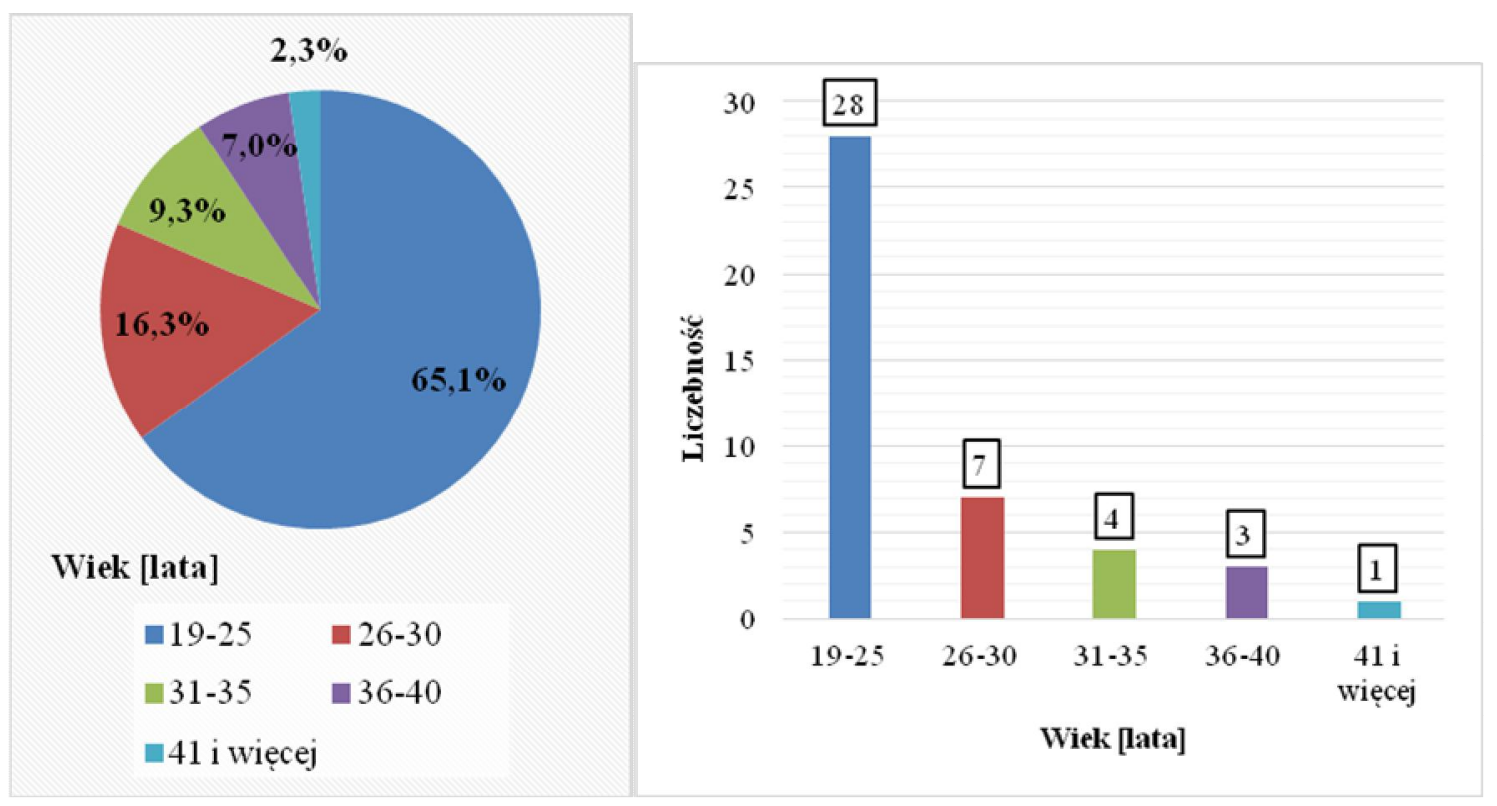

Źródło: opracowanie własne

\section{Wyniki}

Zaprezentowane $\mathrm{w}$ opracowaniu wyniki pochodzą z badań pilotażowych. Wskazują one na preferencje studentów w zakresie zachowań zdrowotnych, które kształtują obraz stylu życia. Tabela 1 przedstawia zbiorczą charakterystykę zachowań zdrowotnych studentów ze względu na płeć.

Tabela 1. Zachowania zdrowotne badanych ze względu na ich płeć.

\begin{tabular}{|l|l|c|c|c|c|c|c|}
\hline Lp. Pytanie & $\begin{array}{c}\text { Sumaryczna } \\
\text { l. pkt za } \\
\text { pytanie }\end{array}$ & $\begin{array}{c}\text { Średnia } \\
\text { l.pkt za } \\
\text { pytanie }\end{array}$ & $\begin{array}{c}\text { Suma } \\
\text { u } \\
\text { kobiet }\end{array}$ & $\begin{array}{c}\text { Średnia } \\
\text { l.pkt za } \\
\text { pytanie } \\
\text { wśród } \\
\text { kobiet }\end{array}$ & $\begin{array}{c}\text { Suma u } \\
\text { mężczyzn }\end{array}$ & $\begin{array}{c}\text { Średnia l. } \\
\text { pkt za } \\
\text { pytanie } \\
\text { wśród } \\
\text { mężczyzn }\end{array}$ \\
\hline 1. & Jem dużo warzyw, owoców & 166 & 3,86 & 148 & 3,89 & 18 & 3,60 \\
\hline 2. & Unikam przeziębień & 159 & 3,70 & 146 & 3,84 & 13 & 2,60 \\
\hline 3. & $\begin{array}{l}\text { Poważnie traktuję } \\
\text { wskazówki osób dużo }\end{array}$ & 147 & 3,42 & 128 & 3,37 & 19 & 3,80 \\
\hline 4. & $\begin{array}{l}\text { Wystarczająco } \\
\text { odpoczywam }\end{array}$ & 2,21 & 85 & 2,24 & 10 & 2,00 \\
\hline 5. & $\begin{array}{l}\text { Ograniczam spożywanie } \\
\text { takich produktów, jak } \\
\text { tłuszcze zwierzęce, cukier }\end{array}$ & 128 & 2,98 & 117 & 3,08 & 11 & 2,20 \\
\hline 6. & $\begin{array}{l}\text { Mam zanotowane numery } \\
\text { telefonów służb pogotowia }\end{array}$ & 171 & 3,98 & 152 & 4,00 & 19 & 3,80 \\
\hline 7. & $\begin{array}{l}\text { Unikam sytuacji, które } \\
\text { wpływają na mnie }\end{array}$ & 128 & 2,98 & 111 & 2,92 & 17 & 3,40 \\
\hline
\end{tabular}




\begin{tabular}{|c|c|c|c|c|c|c|c|}
\hline & przygnębiająco & & & & & & \\
\hline 8. & Unikam przepracowania & 99 & 2,30 & 87 & 2,29 & 12 & 2,40 \\
\hline 9. & $\begin{array}{l}\text { Dbam o } \\
\text { odżywianie }\end{array}$ & 155 & 3,60 & 137 & 3,61 & 18 & 3,60 \\
\hline 10. & $\begin{array}{l}\text { Przestrzegam zaleceń } \\
\text { lekarskich wynikających z } \\
\text { moich badań }\end{array}$ & 168 & 3,91 & 149 & 3,92 & 19 & 3,80 \\
\hline 11. & $\begin{array}{l}\text { Staram się unikać zbyt } \\
\text { silnych } \\
\text { napięć }\end{array}$ & 113 & 2,63 & 96 & 2,53 & 17 & 3,40 \\
\hline 12. & Kontroluję swoją wagę ciała & 127 & 2,95 & 109 & 2,87 & 18 & 3,60 \\
\hline 13. & $\begin{array}{lr}\text { Unikam } & \text { spożywania } \\
\text { żywności z konserwantami }\end{array}$ & 128 & 2,98 & 113 & 2,97 & 15 & 3,00 \\
\hline 14. & $\begin{array}{l}\text { Regularnie zgłaszam się na } \\
\text { badania lekarskie }\end{array}$ & 136 & 3,16 & 119 & 3,13 & 17 & 3,40 \\
\hline 15. & $\begin{array}{|lr|}\text { Mam przyjaciół } & \text { i } \\
\text { uregulowane } & \text { życie } \\
\text { rodzinne } & \end{array}$ & 184 & 4,28 & 166 & 4,37 & 18 & 3,60 \\
\hline 16. & Wystarczająco dużo śpię & 100 & 2,33 & 91 & 2,39 & 9 & 1,80 \\
\hline 17. & $\begin{array}{l}\text { Unikam soli i silnie solonej } \\
\text { żywności }\end{array}$ & 135 & 3,14 & 122 & 3,21 & 13 & 2,60 \\
\hline 18. & $\begin{array}{l}\text { Staram się dowiedzieć, jak } \\
\text { inni unikają chorób }\end{array}$ & 144 & 3,35 & 124 & 3,26 & 20 & 4,00 \\
\hline 19. & $\begin{array}{l}\text { Unikam takich uczuć, jak } \\
\text { gniew, lęk i depresja }\end{array}$ & 122 & 2,84 & 107 & 2,82 & 15 & 3,00 \\
\hline 20. & Ograniczam palenie tytoniu & 179 & 4,16 & 165 & 4,34 & 14 & 2,80 \\
\hline 21. & $\begin{array}{ll}\text { Jem } & \text { pieczywo } \\
\text { pełnoziarniste } & \\
\end{array}$ & 150 & 3,49 & 131 & 3,45 & 19 & 3,80 \\
\hline 22. & $\begin{array}{l}\text { Staram się uzyskać } \\
\text { informacje medyczne i } \\
\text { zrozumieć } \\
\text { zdrowia i choroby }\end{array}$ & 161 & 3,74 & 143 & 3,76 & 18 & 3,60 \\
\hline 23. & Myślę pozytywnie & 144 & 3,35 & 125 & 3,29 & 19 & 3,80 \\
\hline 24. & $\begin{array}{l}\text { Unikam nadmiernego } \\
\text { wysiłku fizycznego }\end{array}$ & 124 & 2,88 & 113 & 2,97 & 11 & 2,20 \\
\hline
\end{tabular}

Źródło: opracowanie własne

Jak wynika z danych zaprezentowanych w tabeli 1 najwyższą liczbę punktów uzyskiwali respondenci potwierdzając preferowanie takich zachowań zdrowotnych jak: posiadanie przyjaciół i uregulowanego życia rodzinnego (184 pkt. - średnia liczba pkt.- 4,28), ograniczanie palenia (179 pkt. - średnia liczba pkt. 4,16), notowanie telefonów służb pogotowia ( 171 pkt. średnia liczba pkt. 3,98). Najniższą liczbę punktów studenci otrzymali za wdrażanie takich zachowań zdrowotnych jak: wystarczająco długie odpoczywanie (95 pkt.- średnia liczba pkt. 2,21), unikanie przepracowania (99 pkt. - średnia liczba pkt. 2,30).

W grupie kobiet najwyższą średnią punktów uzyskiwały one za prezentowanie takich zachowań jak: posiadanie przyjaciół i uregulowanego życia rodzinnego (4,37 pkt.), ograniczanie 
palenia tytoniu (4,34 pkt.), notowanie telefonów do służ pogotowia (4pkt.). Z kolei najniższą średnią liczbę punktów respondentki otrzymywały za: wystarczająco długi wypoczynek $(2,24$ pkt.) oraz unikanie przepracowania (2,29 pkt.).

W grupie mężczyzn najwyższą średnią punktów studenci otrzymywali za próby dowiadywania się od innych osób jak unikać chorób (20 pkt. - średnia liczba pkt. 4,00). Z kolei najniższą liczbę punktów mężczyźni uzyskiwali za wdrażanie takich zachowań jak: wystarczająco długi czas przeznaczony na sen ( 9 pkt. - średnia liczba pkt. 1,80), wystarczająco długie odpoczywanie ( 10 pkt. - średnia liczba pkt. 2,00).

Analizując preferencje badanych z uwzględnieniem ich płci w zakresie wystarczająco długiego okresu wypoczynku można zaobserwować, że zarówno kobiety i mężczyźni nie znajdują wystarczającej ilości czasu na odpoczynek (rycina 3).

\section{Rycina 3. Preferowanie wystarczająco długiego okresu wypoczynku przez badanych z uwzględnieniem ich płci.}

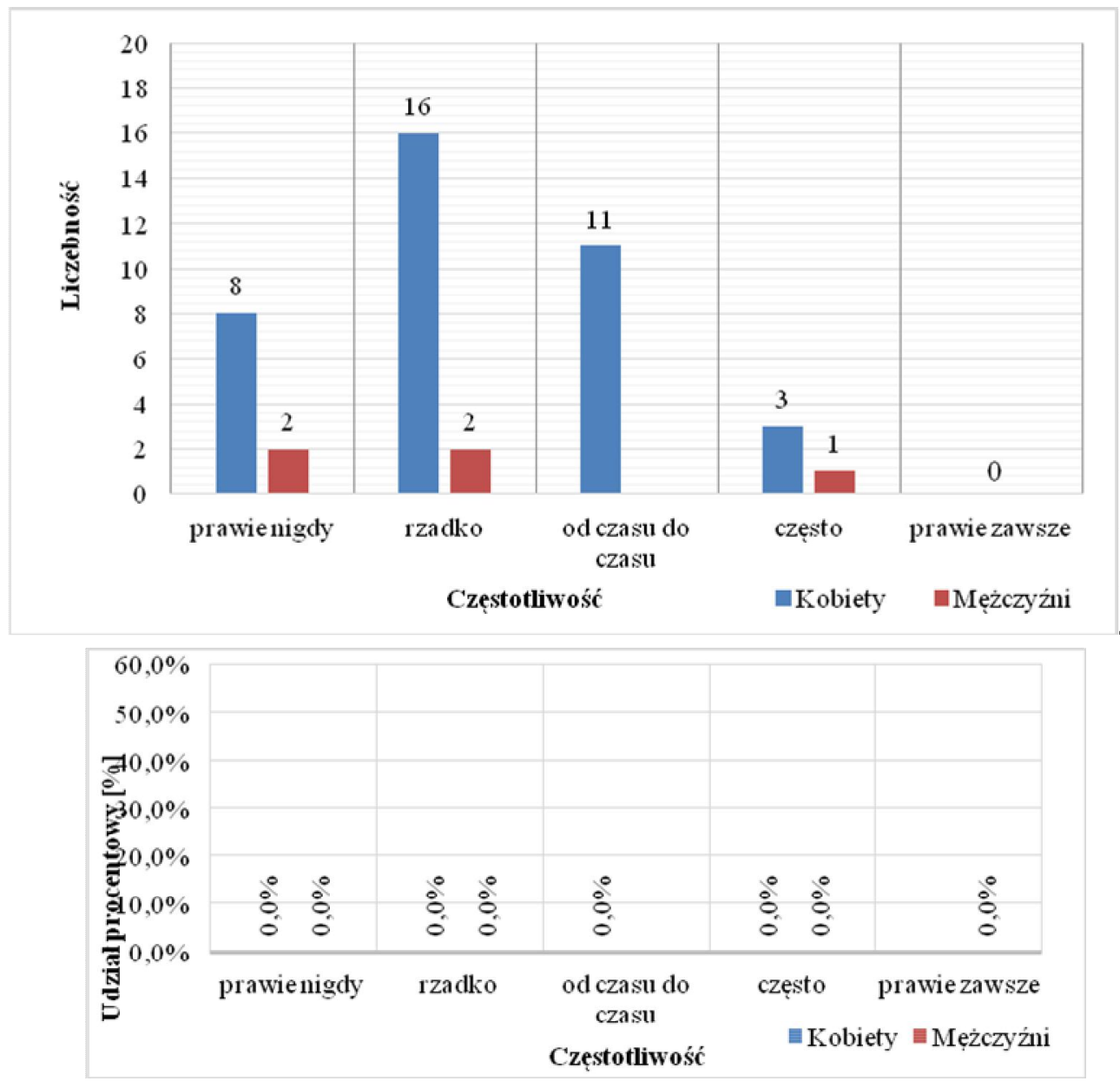

Źródło: opracowanie własne

Jak wynika z ryciny 3 nikt z respondentów niezależnie od płci nie wskazał, że prawie zawsze podejmuje takie działania. Rzadko wystarczająco długo odpoczywa większość kobiet (42,1\% - 16 osób) i mężczyzn (40\% - 2 osoby). Prawie nigdy nie podejmuje takiego działania $40 \%$ respondentów (2 osoby) i 21\% respondentek (8 osób). Często znajduje czas na 
wypoczynek 20,0\% mężczyzn (1 osoba) i 7,9\% kobiet (3 osoby). Od czasu do czasu takie działania podejmują jedynie kobiety (28,9\% - 11 - osób).

Znajomość numerów telefonów służb ratowniczych pozwala na szybkie reagowanie w sytuacjach zagrożenia życia człowieka. W przypadku przyszłych pielęgniarek i pielęgniarzy jest to wręcz niezbędny zasób wiedzy. Rycina 4 prezentuje zachowania respondentów w powyższym zakresie.

\section{Rycina 4. Dysponowanie numerami telefonów służb ratowniczych przez badanych} z uwzględnieniem ich płci.

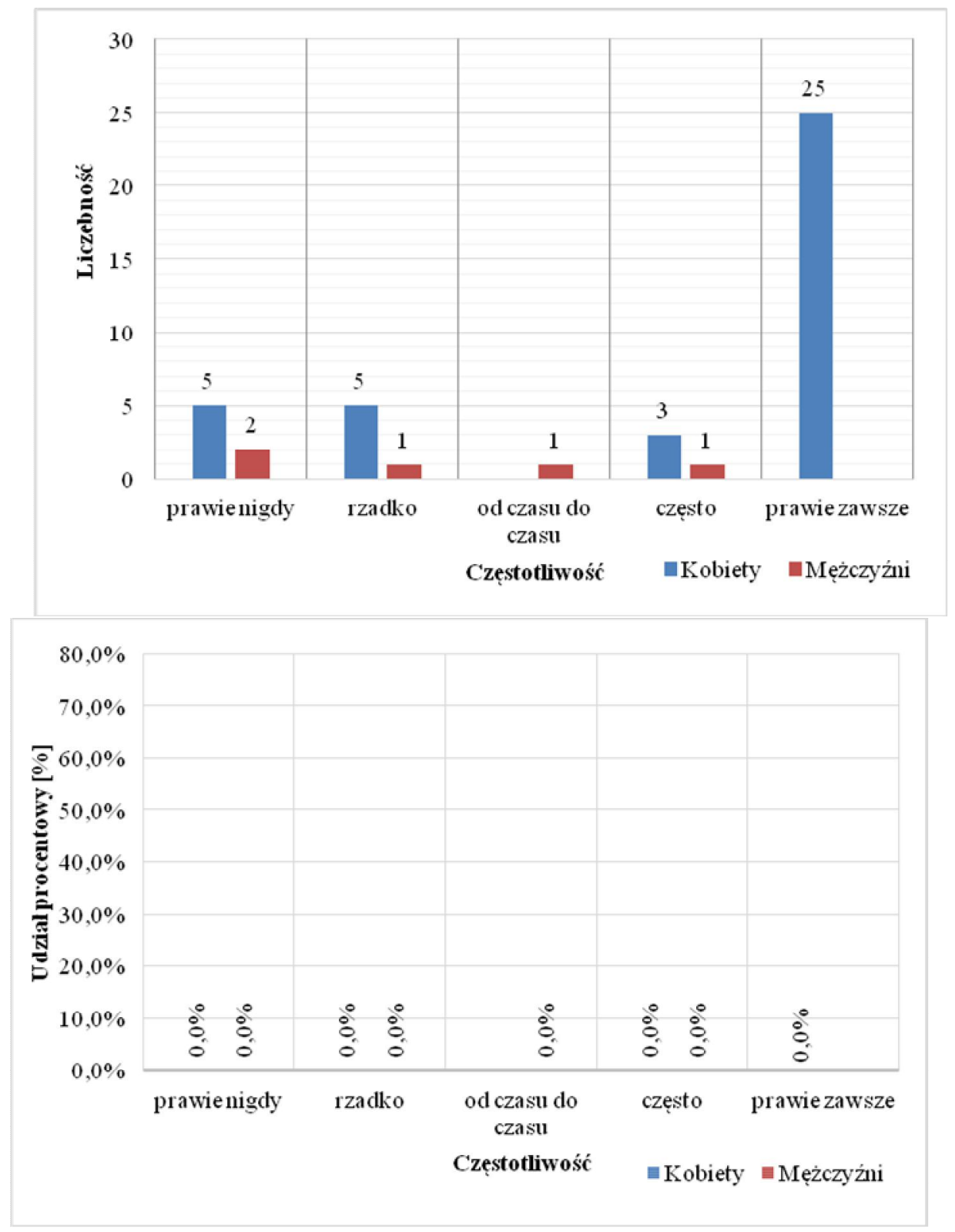

Źródło: opracowanie własne

Z ryciny 4 wynika, że wyłącznie kobiety prawie zawsze deklarują posiadanie numerów telefonów służb ratunkowych (65,8\% - 25 osób). Natomiast prawie nigdy w ich posiadaniu nie jest większość respondentów (40\% - 2 osoby) i tylko 13,2\% respondentek (5 osób). Rzadko takimi numerami dysponuje $20 \%$ mężczyzn (1 osoba) i 13,2\% kobiet (5 osób). Od czasu do 
czasu posiada je tylko 20\% mężczyzn (1 osoba). Natomiast częste dysponowanie nimi podaje $20 \%$ mężczyzn (1 osoba) i 7,9\% kobiet (3 osoby).

Rycina 5 prezentuje preferencje badanych w z uwzględnieniem ich płci w zakresie unikania sytuacji przepracowania.

\section{Rycina 5. Unikanie przepracowania przez badanych z uwzględnieniem ich płci.}

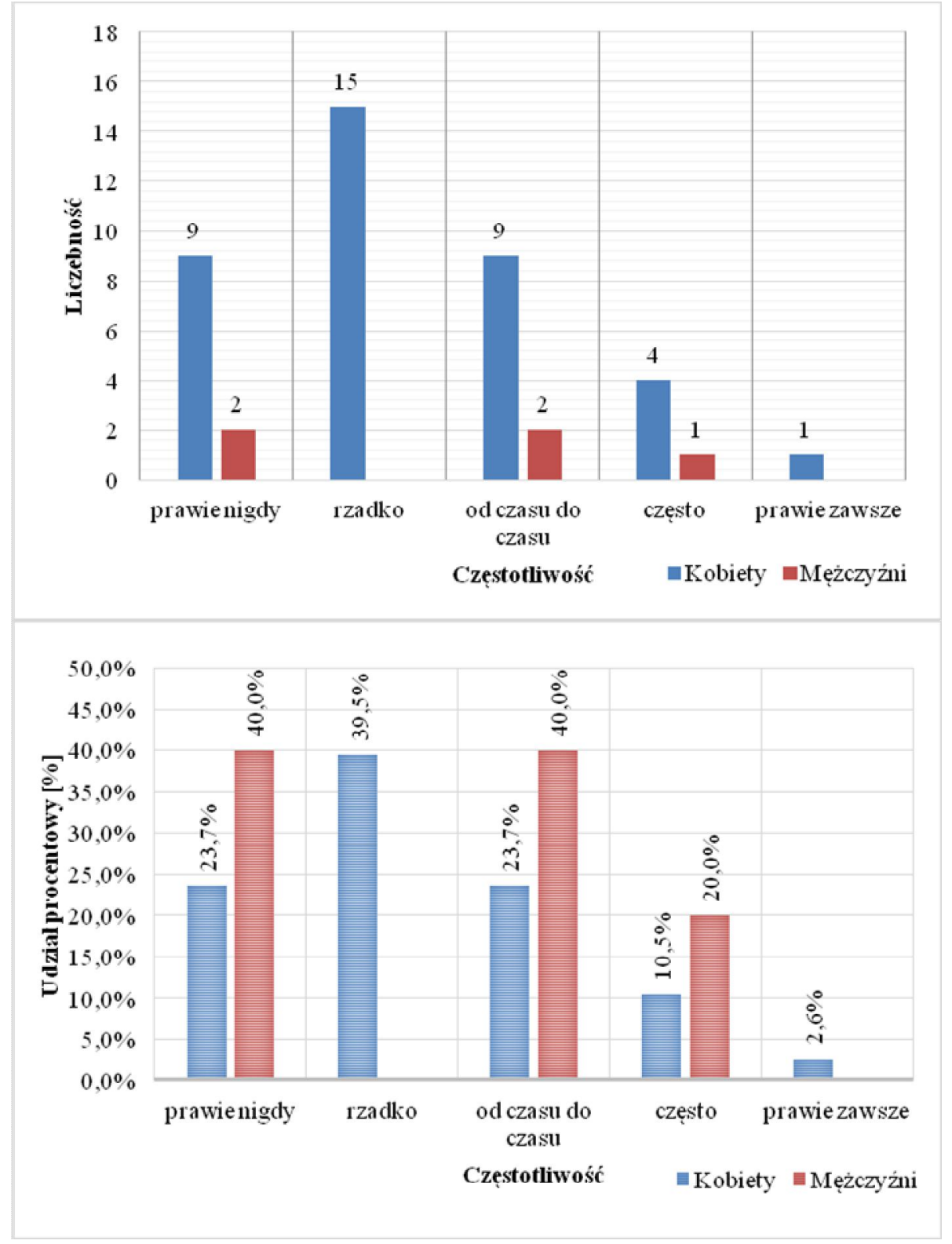

Źródło: opracowanie własne

Jak wynika z ryciny 5 rzadko przepracowania udaje się uniknąć jedynie kobietom (39,5\% -15 osób). Prawie nigdy taka sytuacja nie dotyczy większości respondentów (40\% - 2 osoby) i 23\% respondentek ( 9 osób). Większość mężczyzn (40\% - 2 osoby) i 23,7\% kobiet (9 osób) podaje, że jedynie od czasu do czasu udaje się im uniknąć przepracowania. Często powyższa sytuacja dotyczy $20 \%$ mężczyzn (1 osoba) i 10,5\% kobiet (4 osoby). Prawie zawsze uniknąć przepracowania udaje się jedynie 1 respondentce $(2,6 \%)$.

Rycina 6 prezentuje opinie respondentów z uwzględnieniem ich płci w zakresie posiadania przyjaciół i uregulowanego życia rodzinnego. 


\section{Rycina 6. Posiadanie przyjaciół i regularnego życia rodzinnego przez badanych ze względu na ich płeć.}

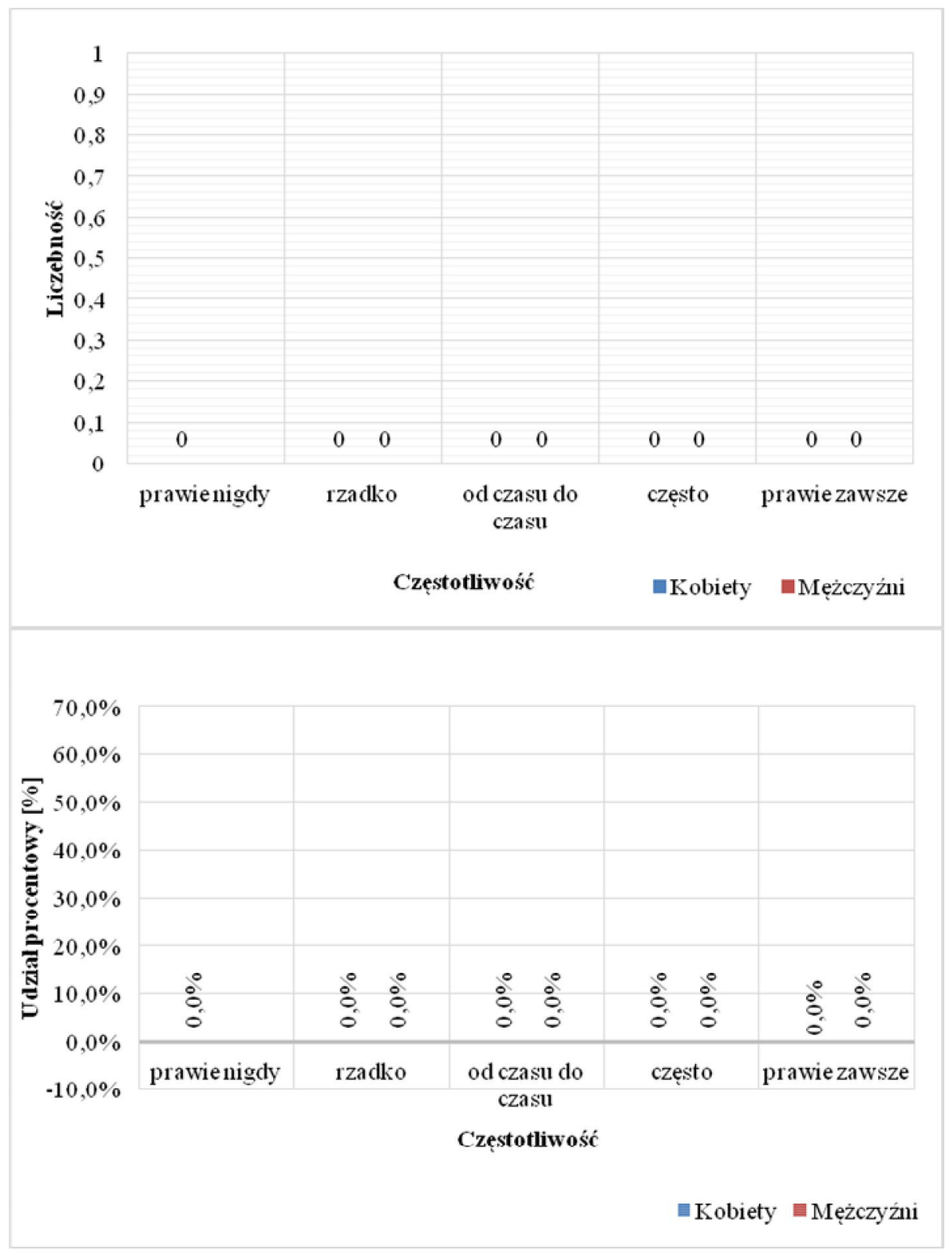

Źródło: opracowanie własne

Jak wynika z ryciny 6 posiadanie przyjaciół i regularnego życia rodzinnego prawie zawsze deklaruje ponad połowa kobiet (55,3\% - 21 osób) i $20 \%$ mężczyzn (1 osoba). Powyższą deklarację jako częstą podało 40\% respondentów (12 osób) i 31,6\% respondentek (2 osoby). Posiadanie przyjaciół i prowadzenie regularnego życia rodzinnego od czasu do czasu wskazało 20\% mężczyzn (1 osoba) i 7,9\% kobiet (3 osoby). Natomiast powyższe zachowanie jako rzadkie podało 20\% mężczyzn (1 osoba) i 5,3\% kobiet (2 osoby). Niezależnie od płci żaden z respondentów nie wskazał, że prawie nigdy nie prowadzi regularnego życia rodzinnego i nie posiada przyjaciół.

Rycina 7 przedstawia prezentuje opinie respondentów $\mathrm{z}$ podziałem na ich płeć w zakresie ograniczania palenia tytoniu. 


\section{Rycina 7. Ograniczanie palenia tytoniu przez badanych z wuwzględnieniem ich płci.}

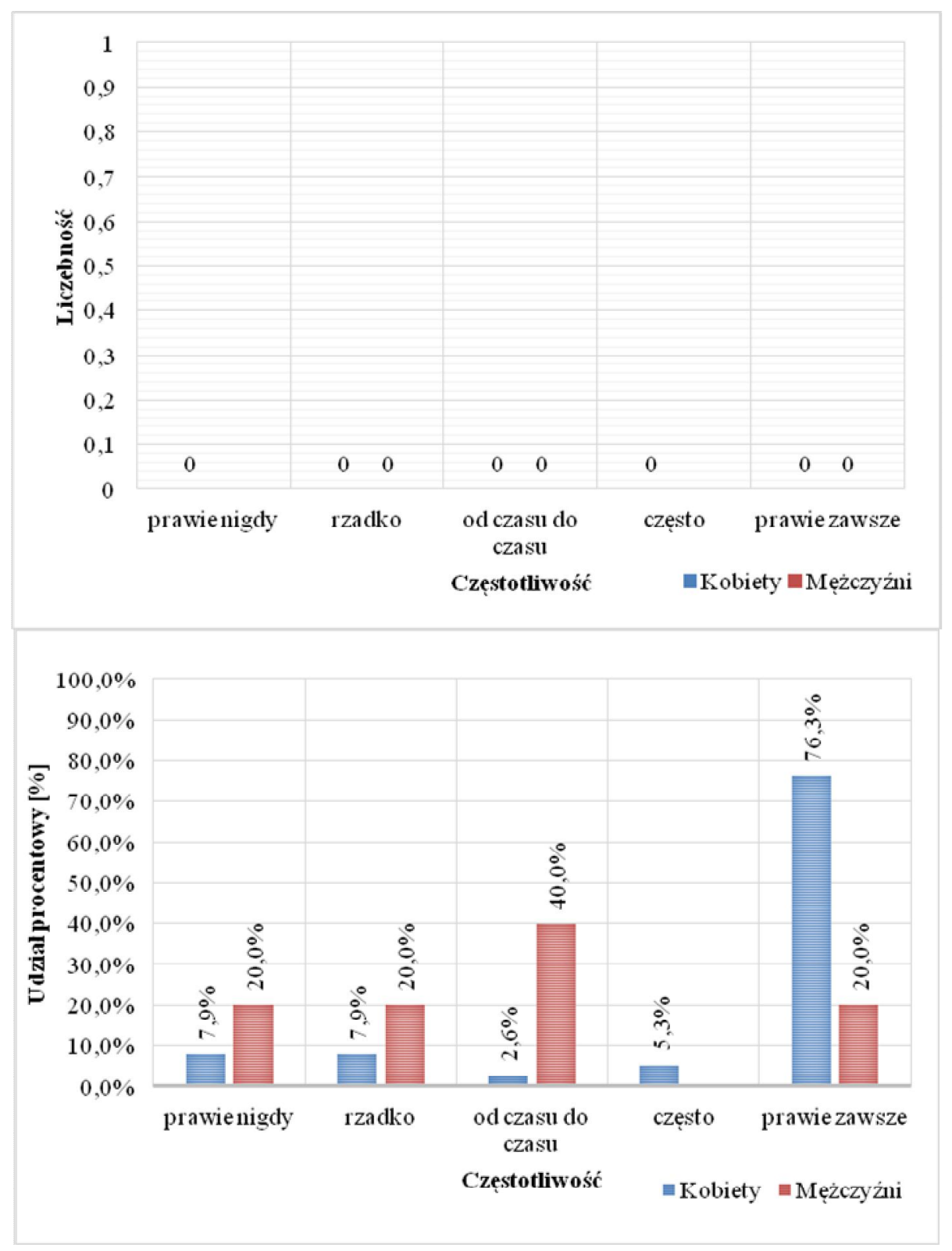

Źródło: opracowanie własne

Prawie zawsze ogranicza palenie tytoniu większość respondentek (76,3\%- 29 osób) i $20 \%$ respondentów (1 osoba). Od czasu do czasu takie działania podejmują częściej męzczyźni (40\% - 2 osoby) niż kobiety (2,6\% - 1 osoba). Rzadko lub prawie nigdy takiego zachowania nie prezentuje odpowiedno po $20 \%$ mężczyzn (po 1 osobie) i odpowiednio po 7,6\% kobiet (po 3 osoby).

\section{Dyskusja}

Wyniki badań władnych z wykorzystaniem IZZ wskazują, że studenci kierunku pielęgniarstwo prezentują zróżnicowany poziom zachowań zdrowotnych, ale stosunkowo satysfakcjonujący. Jest to dobry prognostyk wskazujący na dobre preferencje w zakresie zdrowia osób, które 
w ramach działań zawodowych będą propagować zdrowy styl życia wśród odbiorców świadczeń zdrowotnych [7]. Należy podkreślić, że zachowania prozdrowotne to bardzo aktualny trend, współcześnie szeroko propagowany przez profesjonalistów systemu ochrony zdrowia, ale także media; podkreślany w realizacji programów profilaktycznych i kampanii społecznych. Wpisany jest także w politykę zdrowotną państw.

Jak wynika z badań własnych respondenci najczęściej deklarowali preferowanie takich zachowań zdrowotnych jak: posiadanie przyjaciół i uregulowanego życia rodzinnego, ograniczanie palenia tytoniu, notowanie telefonów służb pogotowia. Niepokojącą sytuacją jest jednak przeznaczanie zbyt małej ilości czasu na wypoczynek i dążenia do unikania przepracowania. Szczególnie pozytywnym elementem stylu życia jest unikanie palenia tytoniu przez badanych. Świadczyć to może o świadomości konsekwencji i negatywnych skutków uzależnienia od tytoniu, który jest czynnikiem ryzyka wielu chorób przewlekłych [8].

Analizując wyniki badań własnych zaobserwowano, że przedstawiciele obu płci starają się $\mathrm{w}$ podobnym stopniu wdrażać praktyki zdrowotne. Jednakże zauważalne są różnice odpowiedziach na niektóre pytania zależne od płci respondentów, co potwierdził także Baumgart $\mathrm{t}[9]$. W badanej przez Suligę grupie studentów płeć również była tym czynnikiem, który najbardziej różnicował zachowania zdrowotne [10]. W projekcie HEPRO oraz w wynikach badań WOBASZ odnotowano częstsze spożywanie owoców i warzyw przez kobiety. Mężczyźni uzyskiwali niższe wyniki $[11,12]$.

Studenci kierunku pielęgniarstwo $\mathrm{w}$ trakcie studiów doskonalą swoje kompetencje w zakresie promowania prawidłowych zachowań zdrowotnych. Zasadnym jest, aby preferencje prozdrowotne dotyczyły $\mathrm{w}$ pierwszej kolejności ich samych, ale także rodziny i osób w najbliższym otoczeniu, jako swoistej sieci wsparcia społecznego. Zmiany preferowanych zachowań zdrowotnych są bowiem możliwe [13].

\section{Wnioski}

Przeprowadzone badania i analiza ich wyników pozwalają stwierdzić, że:

1. Studenci kierunku pielęgniarstwo prezentują dobre postawy i preferencje w zakresie zachowań zdrowotnych.

2. Płeć różnicowała wybrane zachowania zdrowotne badanych.

\section{Zalecenia dla praktyki pielęgniarskiej}

Prezentowanie przez studentów kierunku pielęgniarstwo prozdrowotnych wyborów w zakresie zdrowia i zachęcenie do zachowania takiego stanu akceptacji, umożliwi ich aktywne i wiarygodne włączenie się $\mathrm{w}$ kompleksowe działania interdyscyplinarnych zespołów terapeutycznych na rzecz zdrowia odbiorców świadczeń.

\section{Bibliografia/Bibliography:}

1. Kulik T., Latalski M. (red.). Zdrowie publiczne. Podręcznik dla studentów i absolwentów wydziałów pielęgniarstwa i nauk o zdrowiu akademii medycznych. Wyd. Czelej. Lublin 2002.

2. Wysocki M.J., Miller M. Paradygmat Lalonde’a, Światowa Organizacja Zdrowia i nowe zdrowie publiczne. Przegląd Epidemiologiczny. 2003; 57; 505-12.

3. Wojnowski J. Wielka Encyklopedia PWN. Wyd. PWN. Warszawa 2001. 
4. Denys A. Zagrożenia zdrowia publicznego. Wyd. Wolters Kluwer. Kraków 2014.

5. Rozporządzenie Ministra Nauki i Szkolnictwa Wyższego z dnia 9 maja 2012 r. w sprawie standardów kształcenia dla kierunków studiów: lekarskiego, lekarsko-dentystycznego, farmacji, pielęgniarstwa i położnictwa (Dz. U. 2012 poz. 631).

6. Juczyński Z. Narzędzia pomiaru w promocji i psychologii zdrowia. Pracownia Testów Psychologicznych, Warszawa 2009.

7. Cymerys M., Andrzejewska M., Nowicki M., Kałos U., Klimczak M. Nawyki żywieniowe lekarzy oraz osób z wyższym wykształceniem niemedycznym - analiza porównawcza. Endokrynol Otyłość. 2009; 5(3); 141-142.

8. Rasińska R., Nowakowska I. Palenie tytoniu wśród studentów- porównanie badań własnych z literaturowymi. Przegl Lek. 2012; 69 (10); 888-892.

9. Baumgart M. Zachowania zdrowotne studentów fizjoterapii. Journal of Education, Health and Sport. 2015;5(6); 211-224.

10. Suliga E. Zachowania zdrowotne studentów i uczniów. Wydawnictwo Akademii Świętokrzyskiej. Kielce 2004.

11. Iwanowicz E. Raport o stanie zdrowia poznaniaków $\mathrm{z}$ badania ankietowego $\mathrm{w}$ ramach projektu HEPRO - Zbiór Narzędzi dla Profili Zdrowotnych. Wydawnictwo Miejskie. Poznań 2007.

12. Sygnowska E., Waśkiewicz A., Głuszek J. i wsp. Spożycie produktów spożywczych przez dorosłą populację Polski. Wyniki Programu WOBASZ. Kardiologia Polska. 2005; 63, IV: 6.

13. Binkowska-Bury M, Marć M, Januszewicz P. Wiedza o zdrowiu a zachowania ryzykowne w środowisku młodzieży akademickiej. Medycyna Ogólna. 2010; 16(XLV); 1: 100-112. 